\title{
Sistem Monitoring Kedalaman Dan Kekeruhan Air Berbasis Internet Of Things
}

\author{
Nurdian Herlambang ${ }^{1}$, Rully Pramudita ${ }^{2, *}$, Endang Retnoningsih ${ }^{3}$ \\ ${ }^{1}$ Teknik Informatika; Universitas Bina Insani; Jl. Siliwangi No. 6 Rawa Panjang, Bekasi Barat, \\ Telp 02188958130; e-mail: nurdianherlambang.as@gmail.com \\ ${ }^{2}$ Manajemen Informatika; Universitas Bina Insani; Jl. Siliwangi No. 6 Rawa Panjang, Bekasi \\ Barat, Telp 02188958130; e-mail: rullypramudita@binainsani.ac.id \\ ${ }^{3}$ Sistem Informasi; Universitas Bina Insani; Jl. Siliwangi No. 6 Rawa Panjang, Bekasi Barat, \\ Telp 02188958130; e-mail: endangretnonignsih@binainsani.ac.id
}

* Korespondensi: e-mail: rullypramudita@binainsani.ac.id

Diterima: 10 Desember 2020; Review: 22 Desember 2020; Disetujui: 29 Desember 2020

Cara sitasi: Herlambang N, Pramudita R, Retnoningsih E. 2020. Sistem Monitoring Kedalaman Dan Kekeruhan Air Berbasis Internet Of Things. Information Management for Educators and Professionals. Vol 5 (1): 75 - 84.

\begin{abstract}
Abstrak: Berdasarkan hasil penelitian yang dilakukan terdapat masalah yang ditemukan yaitu pada saat proses penggecekan kedalaman dan kekeruhan kualitas air masih menggunakan sistem secara manual yang melibatkan peran karyawan dalam melakukan proses penggecekannya dengan menggunakan alat turbidity meter dan level transmitter. Oleh sebab itu peneliti memberikan masukkan dan saran untuk proses penggecekan kedalaman dan kekeruhan air tersebut menggunakan sensor dalam mendapatkan hasil penggecekannya dan sistem berbasis internet of things untuk memonitoring hasil dari sensor yang digunakan. Lalu hasil dari prosesnya dapat dimonitoring langsung kedalam platform website. Didalam penelitian ini penulis menggunakan metode logika fuzzy logic untuk memprogram perangkat kerasnya dan hasil monitoringnya menggunakan website dengan framework codeigneter. Yang bertujuan untuk membangun sistem monitoring penggecekan kedalaman dan kekeruhan kualitas air secara otomatis menggunakan sensor ultrasonic dan sensor turbidity.
\end{abstract}

Kata kunci: fuzzy logic, internet of things, sensor turbidity, sensor ultrasonic, sistem monitoring

\begin{abstract}
Based on the results of the research conducted, there were problems found that when the process of checking the depth and turbidity of water quality was still using a manual system that involved the role of employees in carrying out the checking process using a turbidity meter and level transmitter. Therefore, researchers provide input and suggestions for the process of checking the depth and turbidity of the water using sensors to get the results of checking and an internet of things based system to monitor the results of the sensors used. Then the results of the process can be monitored directly into the website platform. In this research, the writer uses fuzzy logic logic method to program the hardware and the monitoring results use a website with codeigneter framework. Which aims to build a monitoring system for checking the depth and turbidity of water quality automatically using ultrasonic sensors and turbidity sensors..
\end{abstract}

Keywords: fuzzy logic, internet of things, monitoring systems, turbidity sensors, ultrasonic sensors

\section{Pendahuluan}

Sebelum air bersih disalurkan kepada masyarakat, dilakukan pengecekan kualitas air sehingga mendapatkan kualitas air yang layak untuk dikomsumsi dan bersih. Namun terdapat kekurangan pada saat proses pengecekan kedalaman dan kekeruhan kualitas air, masih menggunakan peran karyawan dalam melakukan pengecekannya secara manual 
menggunakan alat Turdibity meter untuk mengecek kekeruhan air dan Level Transmitter untuk mengecek kedalaman air. Kemudian hasil dari pengecekan tersebut ditulis kedalam buku laporan hasil pengecekan. Akibatnya, dalam sistem yang sudah berjalan ini dengan menggunakan peran karyawan dapat menyebabkan human error serta kurangnya efisiensi dari segi waktu dan tenaga dalam proses pengecekan kedalam dan kekeruhan air.

Sistem monitoring adalah sistem yang sangat diperlukan dalam sebuah aplikasi. Sistem monitoring disini berperan sebagai pemberi data yang nantinya akan diproses lebih lanjut setelah data terkirim dari sebuah sistem monitoring [1]. Kedalaman air merupakan merupakan level air atau ketinggian air dalam sebuah tempat [2]. Sedangkan Kekeruhan air adalah suatu keadaan dimana transparansi suatu zat cair berkurang akibat kehadiran zat - zat lainnya. Kehadiran zat-zat yang dimaksud terlarut dalam zat cair dan membuatnya seperti berkabut atau tidak jernih [3].

Sistem monitoring kedalaman dan kekeruhan kualitas air yang akan dibuat yaitu menggunakan sistem berbasis website dan internet of things. Internet Of Things atau sering disebut loT adalah sebuah gagasan dimana semua benda di dunia nyata dapat berkomunikasi satu dengan yang lain sebagai bagian dari satu kesatuan sistem terpadu menggunakan jaringan internet sebagai penghubung [4]. Perangkat dan Sensor yang akan digunakan dalam penelitian ini yaitu, pertama wemos, wemos D1 merupakan sebuah perangkat modul wifi berbasis mikrokontroller ESP-8266, wemos D1 memiliki fungsi yang tidak jauh berbeda dengan arduino yang fungsinya sebagai alat pengedali mikro yang bersifat open source, perangkat ini dapat dipakai dalam pengembangan proyek internet of things. Wemos D1 dapat di program dengan menggunakan software Arduino IDE [5]. Kedua Sensor turbinity, sensor Turbidity merupakan Turbidity sensor yang dapat mendeteksi kekeruhan air dengan membaca sifat optic air akibat sinar dan sebagai perbandingan cahaya untuk dipantulkan dengan cahaya yang akan datang [6]. Ketiga sensor ultasonik, sensor ultrasonik adalah sensor $40 \mathrm{khz}$ produksi parallax yang banyak digunakan untuk aplikasi atau kontes robot cerdas. Kelebihan sensor ini adalah hanya membutuhkan 1 sinyal ( SIG ) selain jalur 5 v dan ground [7]. Keempat LCD, LCD (Liquid Crystal Display) sebuah rangkaian yang bertugas untuk monitoring informasi mengenai perangkat sensor yang terhubung [8]. Kelima yaitu buzzer, buzzer merupakan komponen yang berfungsi untuk mengeluarkan suara, prinsip kerjanya pada dasarnya hampir sama dengan loudspeaker, jadi buzzer juga terdiri atas kumparan yang terpasang pada diagfragma dan kemudian kumparan tersebut dialiri arus sehingga menjadi electromagnet [9].

Sistem ini diharapkan dapat mempermudah dan membantu berbagai pekerjaan yang terkait dengan monitoring kualitas air. Terdapat masalah yang ada pada perusahaan waterindo primatech, yaitu saat melakukan pengecekan kedalaman dan kekeruhan air, masih dilakukan secara manual dengan menggunakan peran karyawan harus mengecek pada alat turbidity dan level transmitter.

\section{Metode Penelitian}

Metode Waterfall sering juga disebut model sekuensial linier (sequential linear) atau alur hidup klasik (classic life cycle). Model air terjun menyediakan pendekatan alur hidup perangkat lunak secara sekuensial atau terurut dimulai dari analisis, desain, pengodean, pengujian dan tahap pendukung (support) [10].

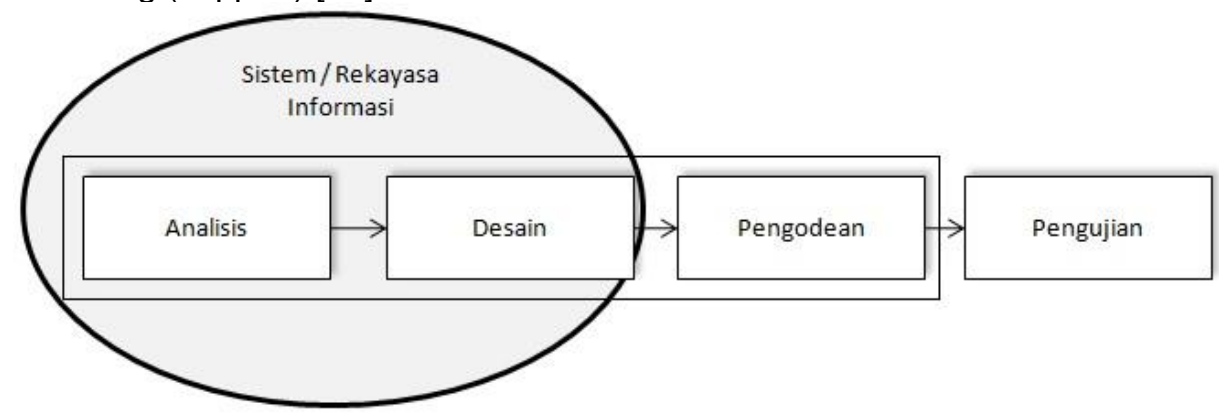

Sumber : [10]

Gambar 1. Model WaterFall 
Berikut adalah tahapan dalam metode : 1). Analisis, berdasarkan analisis dari sistem perangkat keras yang sudah berjalan di PT Waterindo Primatech dalam melakukan proses pengecekan kedalaman air menggunakan Level Transmitter dan pengecekan kekeruhan air menggunakan Turdibity meter. 2). Desain, setelah melakukan proses analisis ditahap kedua ini, dilakukan proses desain. Yang dimana hasil dari analisis tersebut dibuatkan desain perangkat lunak dan perangkat kerasnya. 3). Pengodean, setelah melakukan proses desain, maka pada tahap ini hasil desain akan diterjemahkan dalam bentuk koding yang dimana menggunakan logika fuzzy yang diterapkan kedalam software arduino dan koding php untuk membuat website dan hasil koding dan alat diuji hingga tercapai sesuai dengan peraturan logika fuzzy. Setelah itu hasil dari pengodean akan ditest menggunakan metode black-box yang dimana untuk mengetahui fungsi - fungsi, masukan dan output dari perangkat keras maupun perangkat lunak. 4). Pengujian, setelah melakukan pengodean pada perangkat keras, maka pada tahap ini dilakukannya pengujian terhadap perangkat keras dan alur sistem yang sudah dirancang didalam pengodean tersebut menggunakan arduino. Dengan cara mengisi penampungan pertama dengan air keruh dan penampungan kedua mulai melakukan pengecekan kedalaman dan kekeruhan berdasarkan alur sistem yang dibuat. Setelah itu data hasil sensor akan tampil didalam website dan metode pengujian yang digunakan menggunakan metode black-box, yang dimana pengujiannya ditujukan untuk mengetahui fungsi - fungsi saat menampilkan data, meyimpan data, merubah data, menghapus data dan validasi data sesuai dengan hasil data yang didapatkan sensor.

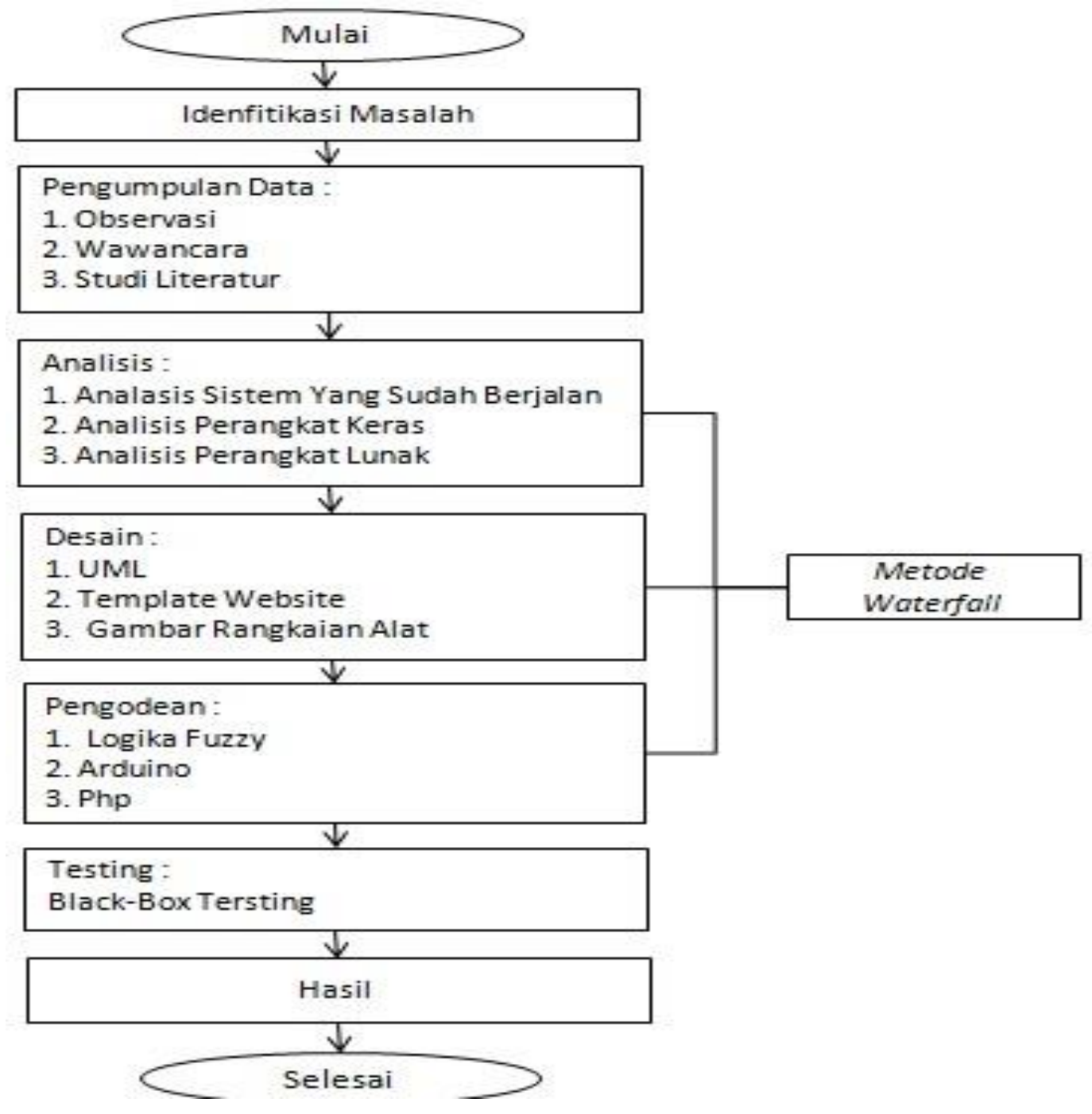

Sumber : Hasil Penelitian (2020)

Gambar 2.Kerangka Pemikiran Sistem Monitoring Kedalaman Dan Kekeruhan Air. 
Berikut ini adalah penjelasan diagram alur dari penelitian yang dilakukan yaitu : 1). Identifikasi Masalah, pada tahap ini dilakukan identifikasi terhadap permasalahan pokok terkait penelitian yang telah dituangkan pada latar belakang masalah yang selanjutnya ditindak lanjuti untuk menemukan solusi yang tepat. 2). Pengumpulan Data, metode pengumpulan data yang digunakan yaitu wawancara, observasi dan studi literatur. 3). Analisa Kebutuhan, analisa di butuhkan untuk mendapatkan informasi - informasi yang terkait dalam penelitian yang nantinya akan di jadikan sebagai bahan acuan, analisa kebutuhan berdasarkan dari identifikasi masalah dan identifikasi sistem yang sedang berjalan. 4). Desain, pada tahap ini dilakukan desain untuk alur program, website, gambaran rangkaian dan rancangan alat berdasarkan analisa kebutuhan yang nantinya akan dituangkan dalam bentuk coding dan testing. 5). Pengodean, pada tahap ini dilakukan proses pengodean menggunakan software arduino untuk memprogram perangkat keras (hardware) dan bahasa php digunakan untuk memprogram hasil monitoring berbasis aplikasi website. 6). Testing, setelah melakukan proses pengodean maka perlu dilakukan testing program menggunakan metode black-box yang bertujuan untuk mengetahui fungsi fungsi dari perangkat keras dan perangkat lunak yang sudah dibuat. 7). Hasil, pada tahapan ini data dari hasil sensor ultrasonik dan sensor turbidity dikirim kedalam database kemudian datanya ditampilkan pada aplikasi website sebagai sistem monitoring kedalaman dan kekeruhan air yang terintegrasi dengan pompa secara otomatis.

\section{Hasil dan Pembahasan}

Perancangan sistem berisi tentang rancangan - rancangan yang akan membuat sebuah sistem agar dapat berjalan sesuai yang diharapkan.

Perancangan Blok Diagram

Untuk menjelaskan perancangan sistem yang dilakukan dalam mewujudkan sistem monitoring kedalaman dan kekeruhan air menggunakan wemos D1 R1 - Website dengan keluaran berupa sistem yang dapat memonitoring hasil dari sensor kedalaman dan kekeruhan air pada PT Waterindo Primatech Bekasi, terlebih dahulu secara umum digambarkan oleh blok diagram sistem kerja yang ditunjukan.

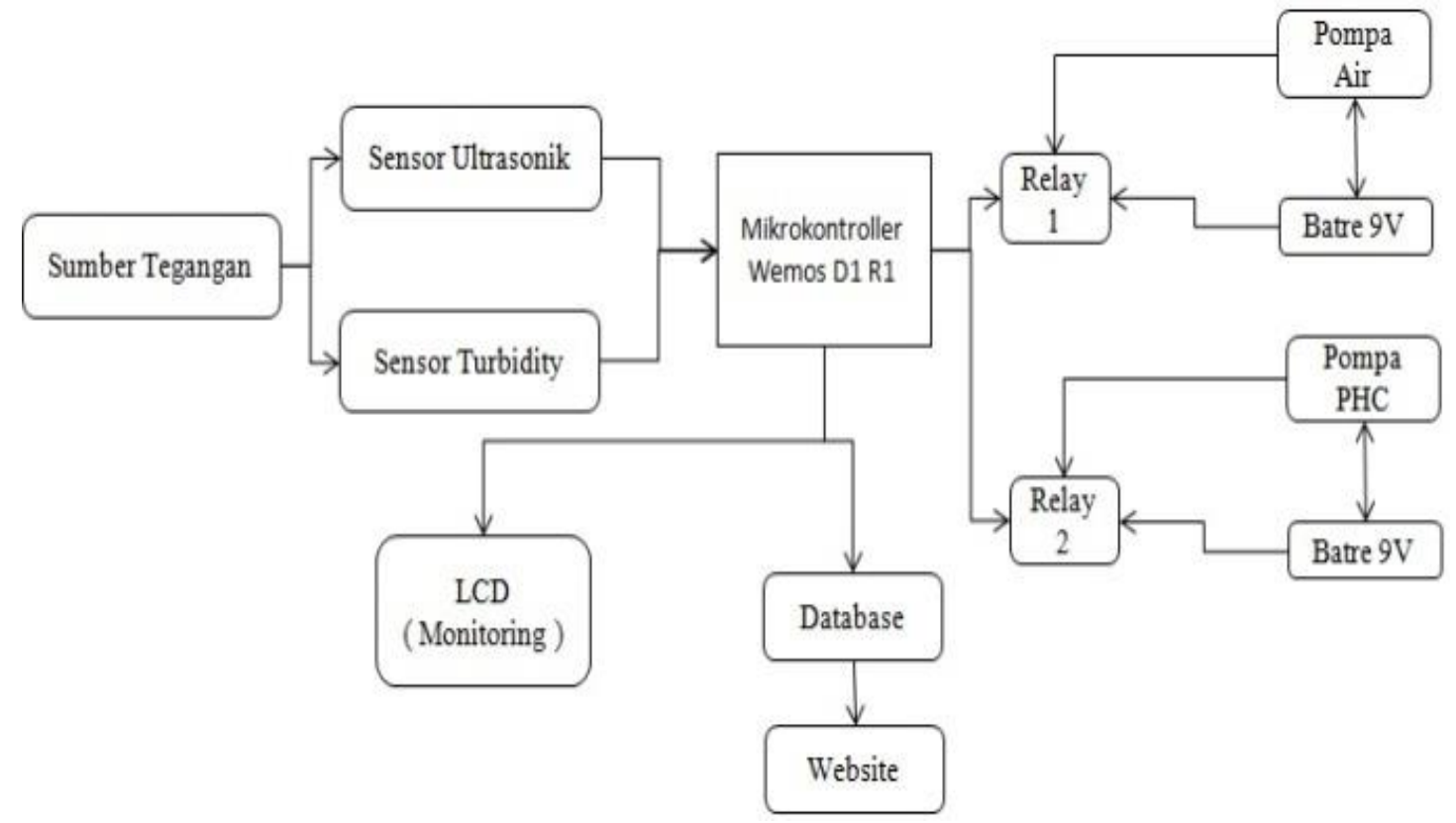

Sumber : Hasil Penelitian (2020)

Gambar 3. Perancangan Blok Diagram

Pada Gambar 5 Sumber daya yang digunakan oleh Wemos D1 adalah tegangan 5 volt dari power bank. Fungsi Wemos D1 sendiri sebagai mikrokontroler yang dapat mengontrol dua sensor yang digunakan yaitu sensor turbidity digunakan untuk mendeteksi kekeruhan dan ultrasonik digunakan untuk mendeteksi kedalaman / ketinggian air. Data hasil pembacaan sensor dapat dilihat di LCD 20x4 dan website sebagai monitoring kedalaman dan kekeruhan air. Perancangan Perangkat Keras 
Adapun Perancangan perangkat keras yang digunakan pada penelitian ini terlihat pada gambar 4 sebagai berikut.

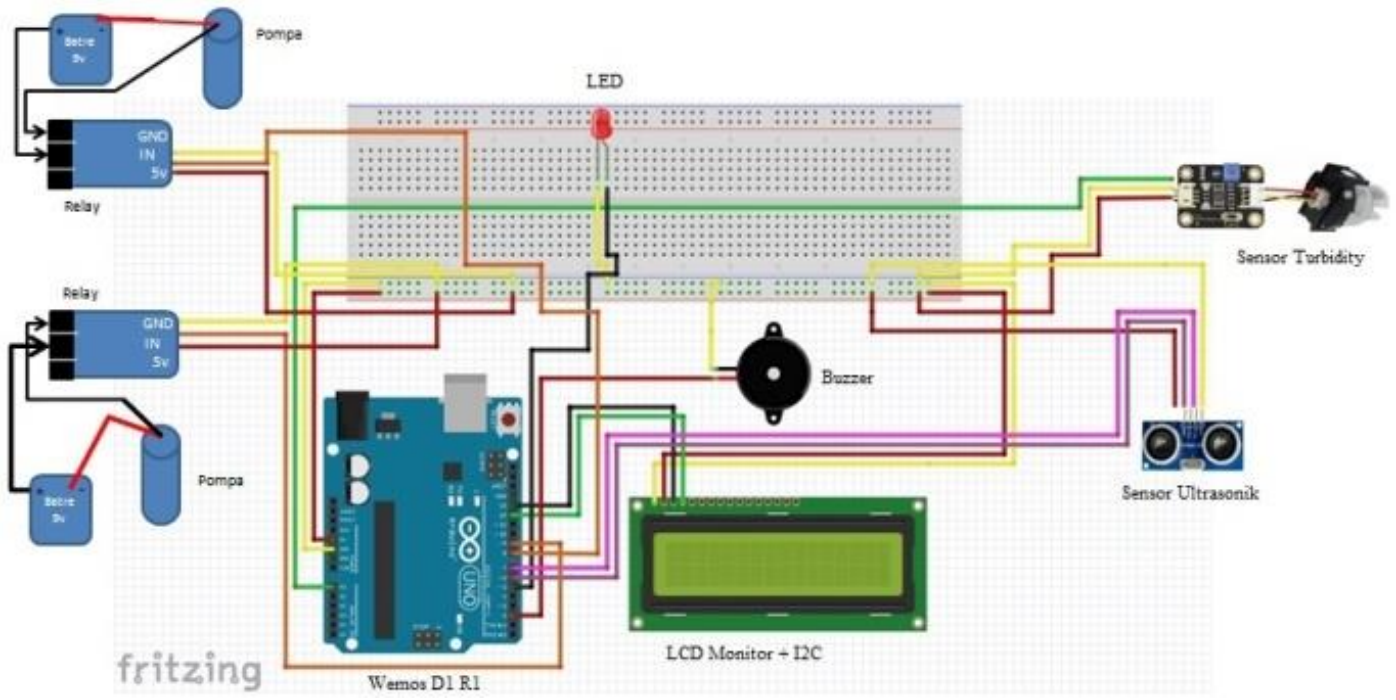

Sumber : Hasil Penelitian (2020)

Gambar 4. Perancangan Perangkat Keras

Pada gambar 4 menunjukan perancangan perangkat keras yang sudah terpasang kabel dan siap untuk dijalankan dengan program Arduino Ide. Untuk rancangan lebih detail dapat dilihat pada tabel 1.

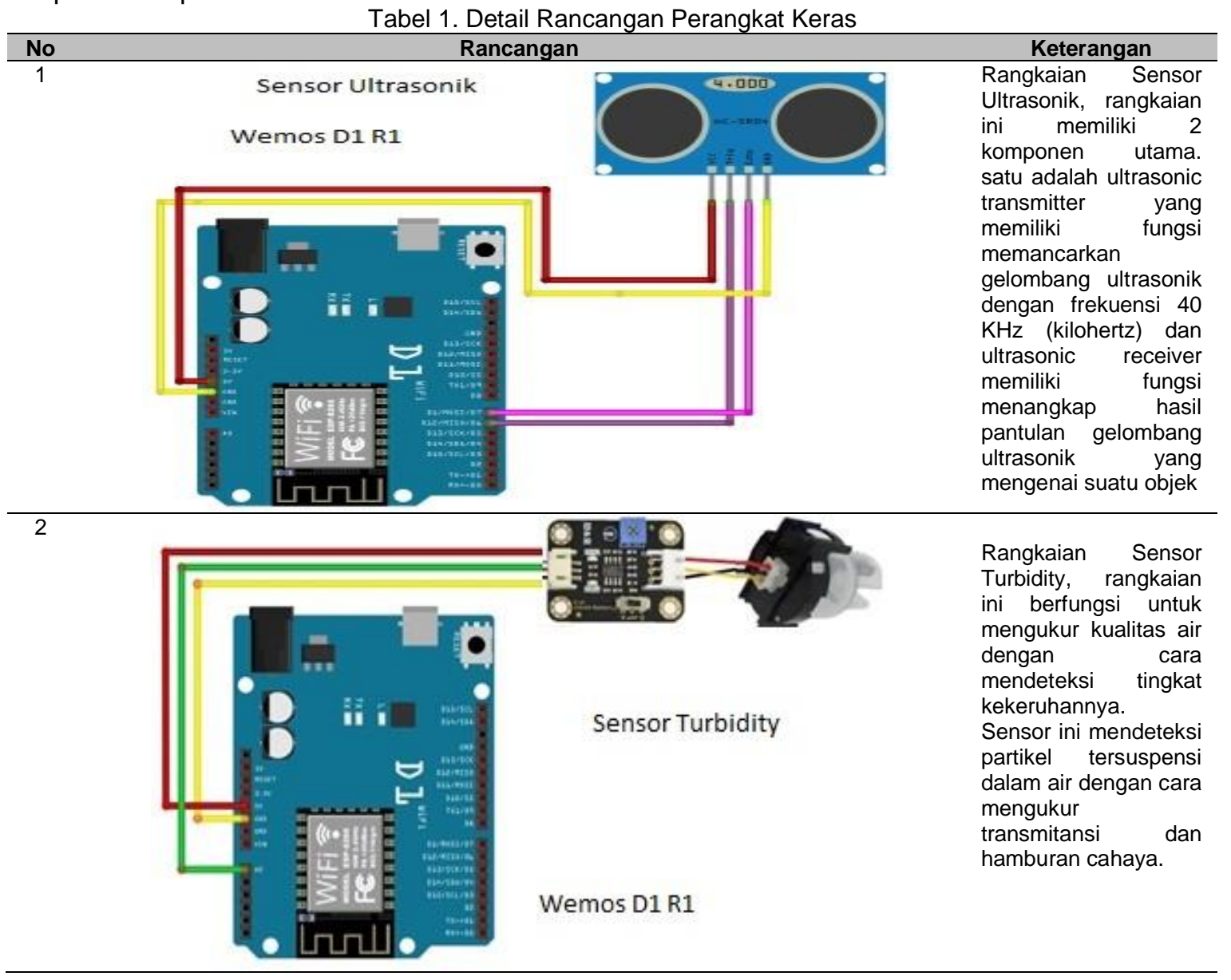




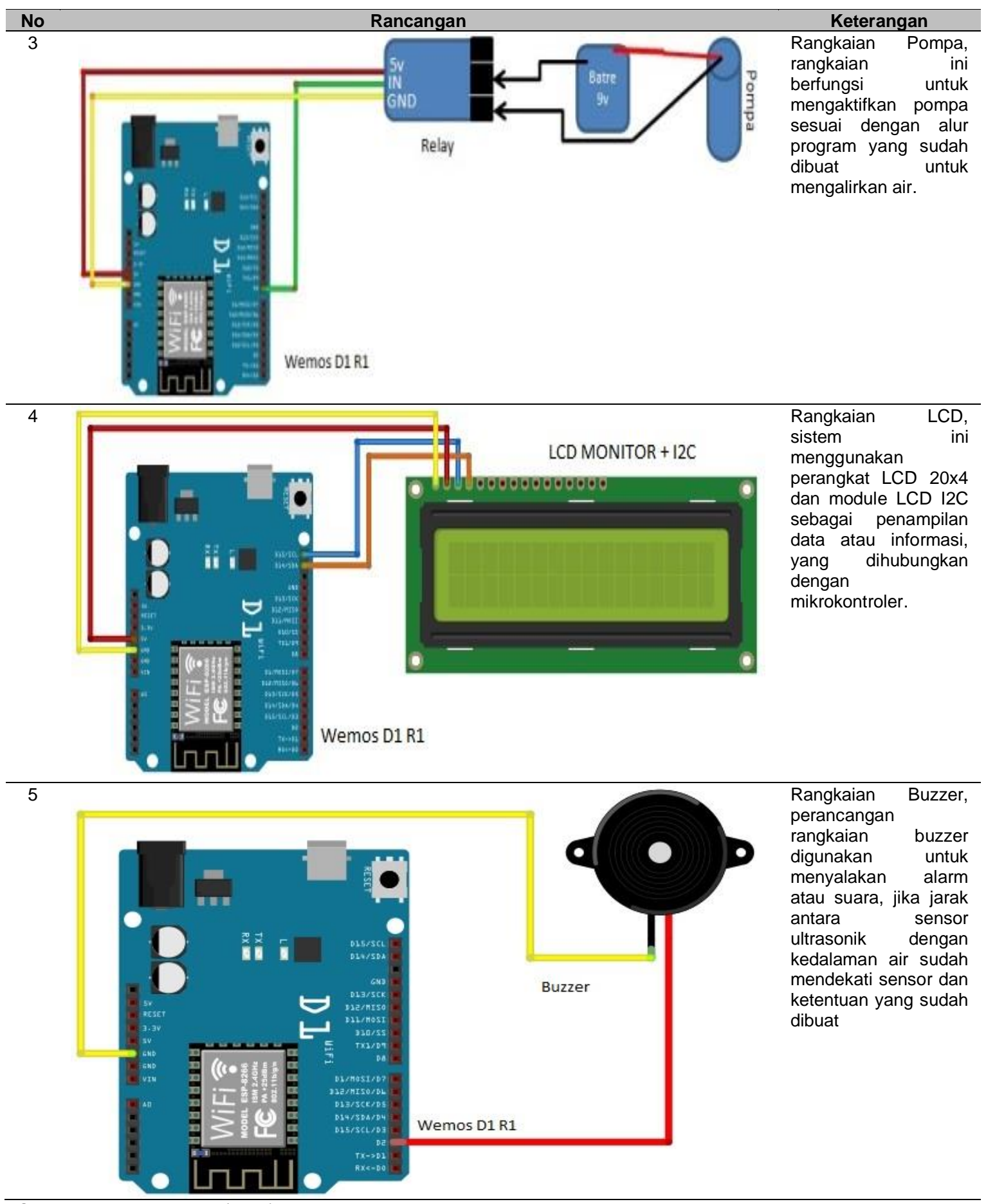

Sumber : Hasil Penelitian (2020)

Implementasi Perangkat Keras, pada tahap ini adalah hasil rancangan perangkat keras secara keseluruhan dari sistem monitoring kedalaman dan kekeruhan air pada PT Waterindo Primatech Bekasi.

Berdasarkan gambar 5 yang sudah dipaparkan terlihat bentuk fisik dari rangkaian sistem monitoring kedalaman dan kekeruhan air yang terdiri dari Wemos D1 R1 yang ada didalam box, Project Board yang ada didalam box, Sensor Ultrasonik diatas permukaan penampungan air bersih, Sensor Turbidity berada di penampungan air bersih untuk mengecek tingkat kekeruhan air, Relay untuk menyalakan dan mematikan pompa, Pompa untuk mendorong air dari penampungan air yang sudah disediakan, Buzzer untuk memberikan tanda jika air sudah mencapai batas yang ditentukan, LED akan menyala jika air sudah mencapai batas dan Lcd 
monitor dengan module LCD I2C akan menampilkan hasil dari data sensor yang sudah didapatkan.

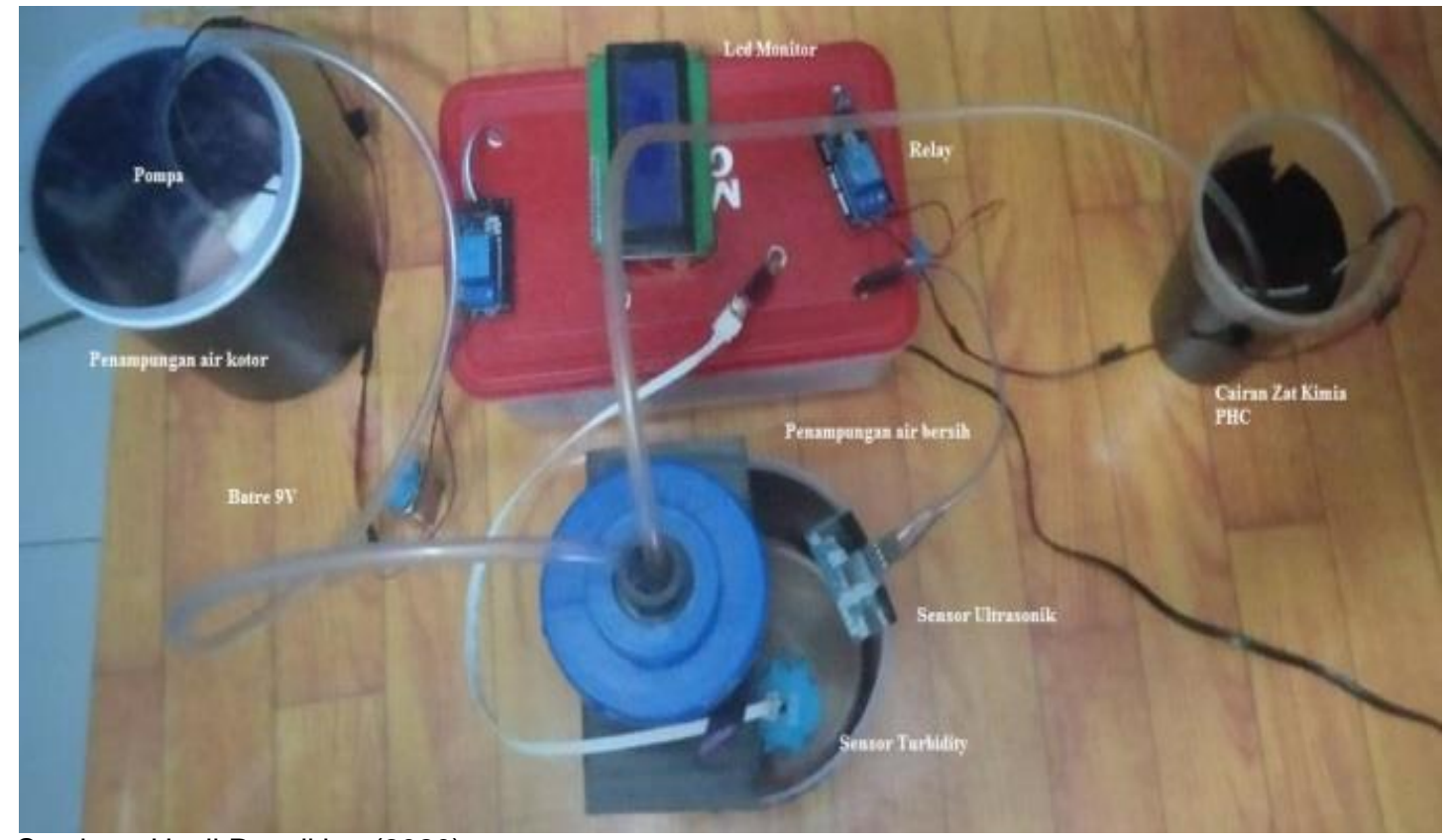

Sumber : Hasil Penelitian (2020)

Gambar 5. Hasil Rancangan Sistem Monitoring Kedalaman Dan Kekeruhan Air

Implementasi Perangkat Lunak, pada tahap ini adalah hasil rancangan perangkat lunak yang berupa aplikasi sistem monitoring kedalaman dan kekeruhan air berbasis website. Tabel 2 menjelaskan tampilan website.

Tabel 2. Tampilan Halaman Website

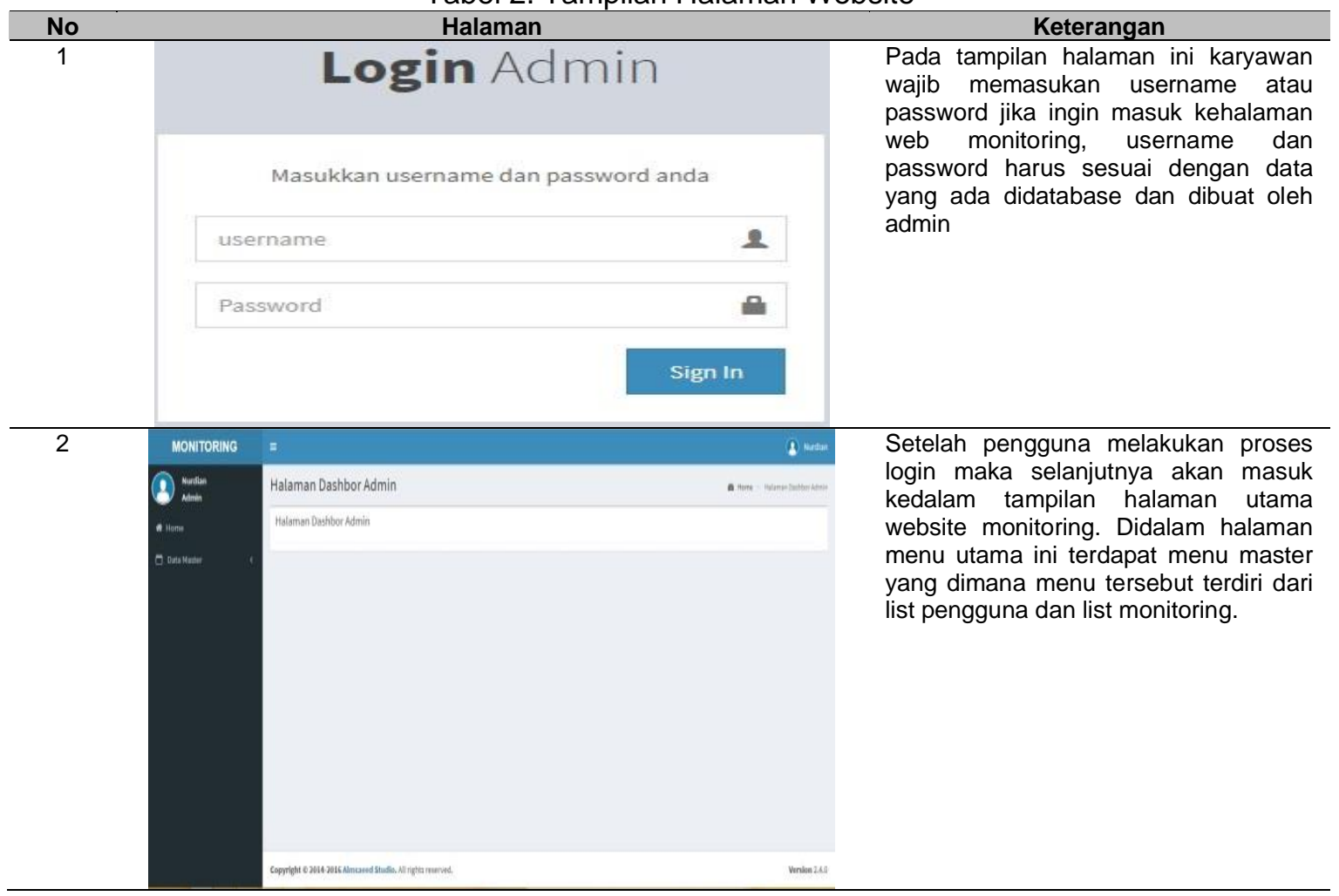




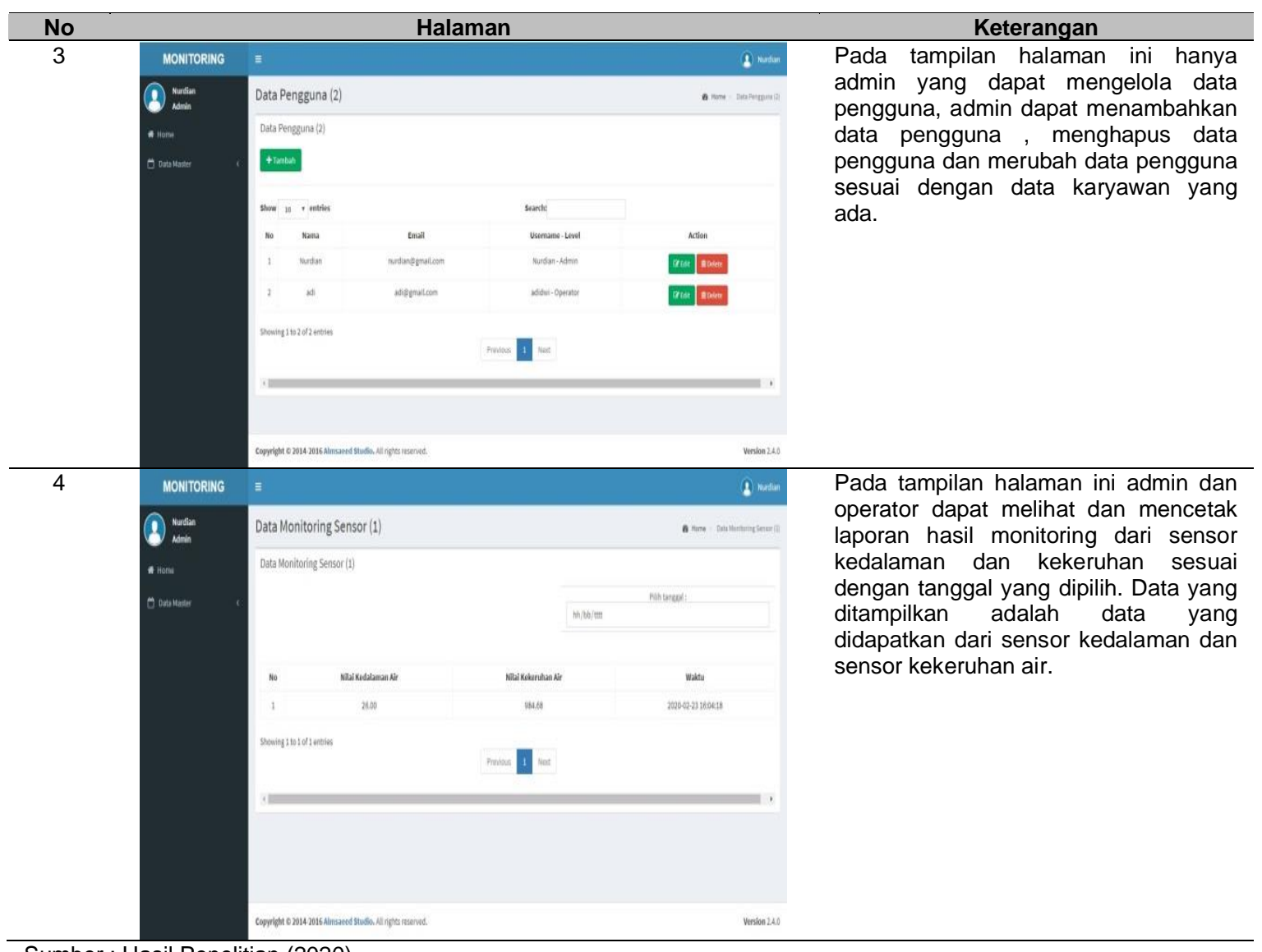

Sumber : Hasil Penelitian (2020)

Pengujian Sistem, Adapun pengujian sistem yang digunakan dalam penelitian ini adalah Black Box Testing. Pengujian dimaksudkan untuk mengetahui apakah semua fungsi - fungsi dapat berjalan sesuai dengan yang diharapkan tanpa menguji desain dan kode program. Berikut ini adalah hasil pengujian black box testing pada halaman login admin dan operator:

Tabel 3. Hasil Pengujian Halaman Login Pada Aplikasi Sistem Monitoring

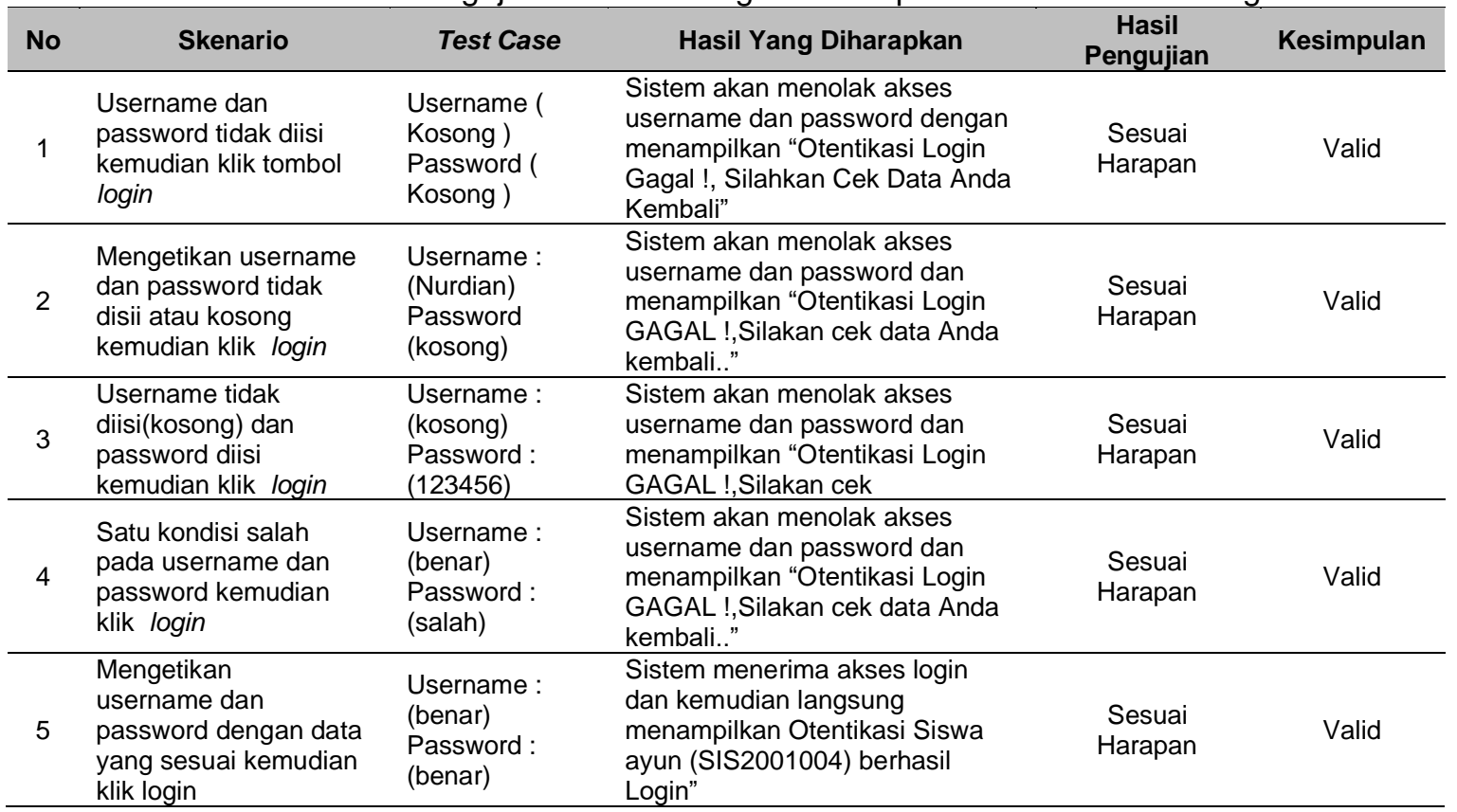

Sumber : Hasil Penelitian (2020) 
Berikut ini adalah hasil pengujian black box testing pada halaman list data pengguna dapat dilihat pada tabel 4 .

Tabel 4. Hasil Pengujian Halaman Pengelolahan

Pengguna Pada Aplikasi Sistem Monitoring

\begin{tabular}{cccccc}
\hline No & Skenario & Test Case & Hasil Yang Diharapkan & Hasil Pengujian & Kesimpulan \\
\hline 1 & $\begin{array}{l}\text { Masuk kehalaman } \\
\text { Pengguna }\end{array}$ & Klik Button Add & Menampilkan form tambah & Sesuai Harapan & Valid \\
\hline 2 & $\begin{array}{l}\text { Masuk kehalaman } \\
\text { Pengguna }\end{array}$ & Klik Button Edit & $\begin{array}{l}\text { Menampilkan data yang akan } \\
\text { di edit berdasarkan database } \\
\text { lalu muncul di form edit }\end{array}$ & Sesuai Harapan & Valid \\
\hline 3 & $\begin{array}{l}\text { Masuk kehalaman } \\
\text { Pengguna }\end{array}$ & Klik Button Delete & Hapus data yang diinginkan & Sesuai Harapan & Valid \\
\hline
\end{tabular}

Sumber : Hasil Penelitian (2020)

Berikut tabel 5 adalah beberapa rules pengujian yang dilakukan berdasarkan sensor ultrasonik dan sensor turbidity pada WEMOS D1 R1 dengan kendali pompa :

Tabel 5. Hasil Pengujian Kendali Pompa Otomatis Pada Aplikasi Sistem Monitoring

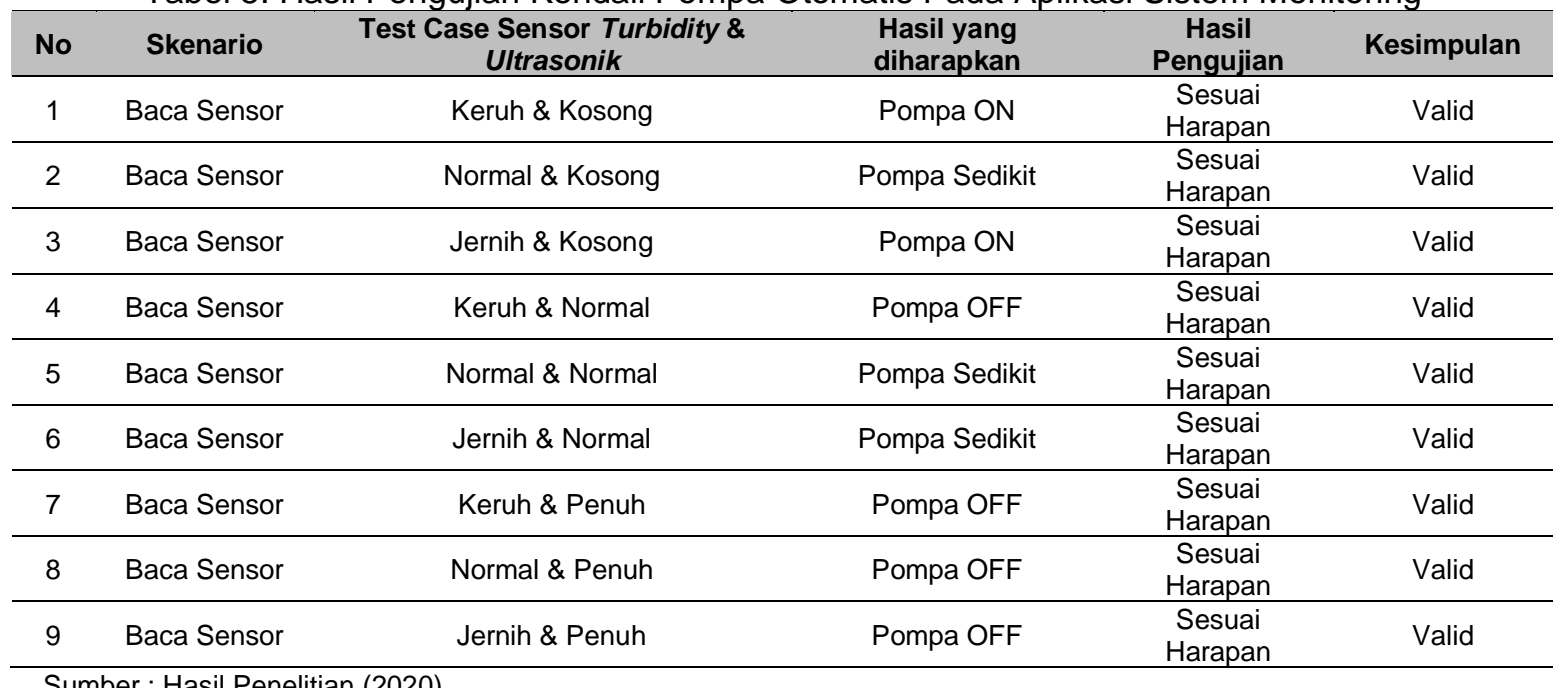

Sumber : Hasil Penelitian (2020)

Berdasarkan pengujian yang telah dipaparkan dapat disimpulkan bahwa monitoring kedalaman dan kekeruhan air dengan perangkat keras WEMOS D1 R1 mampu mengendalikan pompa secara otomatis dengan batas kedalaman dan batas kualitas air berdasarkan sensor dan rules yang sudah ditentukan. Setelah dilakukan pengujian terhadap aplikasi sistem monitoring kedalaman dan kekeruhan air untuk mengendalikan pompa secara otomatis, diperoleh bahwa setiap komponen pada perangkat sistem monitoring dapat bekerja dengan baik tanpa kendala. WEMOS D1 R1 sebagai mikrokontroller dan website sebagai monitoring hasil data sensor. Sehingga sistem monitoring dapat berjalan dengan sesuai yang diharapkan.

\section{Kesimpulan}

Beberapa Kesimpulan yang didasarkan pada penelitian ini, sistem usulan yang dibuat oleh peneliti dapat membantu pada saat proses pengecekan kedalaman menggunakan sensor ultrasonik dan kekeruhan air menggunakan sensor turbidity yang sesuai dengan logika yang telah diterapkan berdasarkan hasil penelitian. Sistem usulan yang dibuat oleh peneliti dapat menyimpan data hasil dari sensor masuk kedalam database mysql. jika data baca sensor sudah sesuai dengan logika yang telah diterapkan. Sistem usulan yang dibuat oleh peneliti adalah sistem monitoring kedalaman dan kekeruhan air yang teringrasi dengan pompa secara otomatis dan penyimpanan hasil data sensor langsung masuk kedalam database secara realtime sesuai dengan logika yang sudah disesuaikan.

\section{Referensi}

[1] M. Kautsar, R. Isnanto, and E. Widianto, "Sistem Monitoring Digital Penggunaan dan Kualitas Kekeruhan Air PDAM Berbasis Mikrokontroler ATMega328 Menggunakan Sensor Aliran Air dan Sensor Fotodiode.," J. Teknol. Dan Sist. Komput., vol. 3, no. 1, pp. 
79-86, 2016.

[2] H. Suryantoro et al., "Prototype Sistem Monitoring Level Air Berbasis Labview \& Arduino Sebagai Sarana Pendukung Praktikum Instrumentasi Sistem Kendali ISSN 26554887 ( Print ), ISSN 26551624 ( Online ) ISSN 26554887 ( Print ), ISSN 26551624 ( Online )," Indones. J. Lab., vol. 1, no. 3, pp. 20-32, 2019.

[3] D. Sasmoko and Y. A. Wicaksono, "Implementasi Penerapan Internet Of Things(lot)Pada Monitoring Infus Menggunakan Esp 8266 Dan Web Untuk Berbagi Data," J. IIm. Inform., vol. 2, no. 1, pp. 90-98, 2017.

[4] Y. Efendi, "Internet Of Things (lot) Sistem Pengendalian Lampu Menggunakan Raspberry Pi Berbasis Mobile," J. IIm. IImu Komput., vol. 4, no. 2, pp. 21-27, 2018.

[5] D. Setiadi and M. N. Abdul Muhaemin, "PENERAPAN INTERNET OF THINGS (IoT) PADA SISTEM MONITORING IRIGASI (SMART IRIGASI)," Infotronik J. Teknol. Inf. dan Elektron., vol. 3, no. 2, p. 95, 2018.

[6] A. Noor, "Aplikasi Pendeteksi Kualitas Air Menggunakan Turbidity Sensor Dan Arduino Berbasis Web Mobile," Joutica, vol. 5, no. 1, p. 316, 2020.

[7] S. Sriani, "Pemanfaatan Sistem Pengendali Water Level Control Untuk Budidaya Ikan Gurame Pada Kolam Terpal Menggunakan Logika Fuzzy Berbasis Mikrokontroler," Elkawnie, vol. 5, no. 1, p. 47, 2019.

[8] Handi, H. Fitriyah, and G. E. Setyawan, "Sistem Pemantauan Menggunakan Blynk dan Pengendalian Penyiraman Tanaman Jamur Dengan Metode Logika Fuzzy," J. Pengemb. Teknol. Inf. dan Ilmu Komput., vol. 3, no. 4, pp. 3258-3265, 2019.

[9] F. Rozi, H. Amnur, F. Fitriani, and P. Primawati, "Home Security Menggunakan Arduino Berbasis Internet Of Things," INVOTEK J. Inov. Vokasional dan Teknol., vol. 18, no. 2, pp. 17-24, 2018.

[10] R. A. Sukamto and M. Shalahuddin, Rekayasa perangkat lunak terstruktur dan berorientasi objek. Bandung: Informatika, 2013. 